\title{
КОНЦЕПТ «ДІАЛОГ» У ПУБЛІЦИСТИЦІ СЕРГІЯ АВЕРИНЦЕВА
}

\author{
Андрій Мельник \\ Львівський національний університет імені Івана Франка \\ вул. Генерала Чупринки, 49, 79044, Львів, Україна \\ e-mail: andriy.melnyk@lnu.edu.ua \\ https://orcid.org/0000-0003-1646-008X
}

Предмет дослідження статті - публіцистика російського філолога, історика культури та впливового публічного інтелектуала 1990-х - поч. 2000-х років Сергія Аверинцева, присвячена подоланню тоталітарної спадщини i, зокрема, поняттю «діалог». Наголошено на тому, що діалогічний етос протистоїть усім видам тоталітаризму, який атомізує людину, перетворюючи їі на піддатливий до маніпуляцій матеріал.

Ключові слова: публіцистика; діалог; цінності; Сергій Аверинцев; Росія.

\section{1. Постановка проблеми}

Незважаючи на те, що з часу розпаду СРСР минуло більш ніж чверть сторіччя, спадщина, яку залишила по собі комуністична ідеологія, досі не стала музейним експонатом. Що більше, пострадянська свідомість, індоктринована сумішшю із марксистської філософії та постійного страху від їі репресивного втілення, у парадоксальний спосіб виявилась доволі сприйнятливою до, здавалося б, цілком нової ситуації «постправди». «Залізобетонний» комуністичний диктат та витончений постмодерністський релятивізм виявились однаково руйнівними і для поняття «правда», і для інших цінностей, зокрема й таких, як автентичний діалог.

Російський філолог та історик культури Сергій Аверинцев був тим публіцистом, який, відповідаючи на пострадянський ціннісно-орієнтаційний запит, завдяки своїй академічній компетентності сприяв відновленню автентичного значення понять, зокрема й такого, як «діалог», про яке йтиметься нижче. С. Аверинцев був однією із найпомітніших публічних фігур кінця 80-х - початку 90-х років минулого сторіччя у гуманітарному дискурсі спочатку пізнього СРСР, а потім і посталих на його території незалежних держав. Після нетривалої політичної діяльності він чимало свого творчого часу присвячував публіцистиці. С. Аверинцев був академічним ученим, який на певному етапі своєї кар'єри почав виступати на сторінках суспільно-політичної преси, долучаючись до актуальних суспільних дискусій.

Поняття «діалог» сьогодні настільки міцно вкоренилось у публічній сфері, що кожен, хто претендує на статус публічного інтелектуала і говорить про цінності, використовує його у своєму лексиконі і висловлює своє ставлення до нього. С. Аве-

(C) Мельник А., 2020 
ринцев один з тих авторів, які не оминули увагою діалогічну тематику, що становить важливу частину і його публіцистичного спадку. Мета статті - виокремити головні особливості у трактуванні концепту «діалог» у публіцистиці С. Аверинцева.

\section{2. Теоретичне підгрунтя та методологічна основа дослідження}

Поняття «діалог» у філософському контексті аналізували В. Біблер, М. Бубер, Е. Левінас, В. Малахов, Ф. Розенцвайг та чимало інших дослідників. Також воно стало основою оригінальної світоглядної течії XX сторіччя - філософії діалогу. Однак, зважаючи на те, що сьогодні слово «діалог» стало обов'язковим елементом публічного дискурсу, його варто досліджувати не лише у філософській площині, але й аналізуючи політичну риторику, художню літературу і публіцистичні тексти. Досліджуючи публіцистику С. Аверинцева, ми використовували насамперед тематичний та дискурсивний аналіз.

\section{3. Виклад основного матеріалу дослідження}

Про важливість поняття «діалог» у розумінні сучасних світоглядних тенденцій може свідчити хоча б той факт, що ООН проголосила 2001 рік - перший рік нового тисячоліття - Роком діалогу між цивілізаціями. Цей символічний крок можна вважати своєрідною відповіддю різноманітним похмурим пророцтвам, на кшталт «зіткнення цивілізацій» Семюела Гантингтона. Цікаво, що опрацювання концепції «діалогу між цивілізаціями» приписують колишньому президентові Ірану Мохаммаду Хатамі ${ }^{1}$. «ранський Горбачов», як інколи називали Хатамі за його доволі сміливі у контексті іранської політичної традиції кроки, запропонував її як альтернативу згаданій ідеї американського політолога та концепції «кінця історії» Ф. Фукуями. Хатамі був не єдиним представником ісламського світу, який, впроваджуючи ідеї діалогу, розвіював популярний на Заході стереотип «мусульманина-терориста». Серед його однодумців варто згадати відомого і в Україні турецького мислителя Фетхуллаха Гюлена ${ }^{2}$. Звісно, не варто, базуючись на згадці лише про двох мислителів зі Сходу, робити висновок, що концепція «діалогу цивілізацій» успішна в ісламському світі, тоді як на Заході усі сповідують гантингтонівський підхід. Утім, зважаючи на політичні обставини, голос Сходу у діалозі цивілізацій має особливе значення.

Актуальність поняття «діалог» у науковій та публіцистичній площинах не залишилась поза увагою С. Аверинцева. У його публіцистиці можна знайти і відгуки щодо резонансу діалогічної проблематики, і власні оригінальні міркування.

Сергія Аверинцева, як християнського публіциста, цікавить насамперед релігійний вимір діалогічного спілкування. В есеї «Ми покликані у спілкування» він міркує про «найглибше зі спілкувань» - спілкування з Богом, зазначаючи на початку, що провадити мову про цей різновид спілкування мають право насамперед подвижники, ченці, ті, хто із власного досвіду може розповісти про нього. Але зазвичай такі люди не пишуть статей для світських видань. Натякаючи цим зауваженням на себе, С. Аверинцев визнає - і це притаманно для багатьох його есеїв з релігійної проблематики, - що його тлумачення не претендує на повноту чи тим паче канонічність. Чи може світська віруюча людина говорити про те, що належить до компетенції богослова? С. Аверинцев знаходить вихід із цієї дилеми: для роздумів про діалог

1 Petito, F. (2007), “The Global Political Discourse of Dialogue among Civilizations: Mohammad Khatami and Václav Havel", Global Change, Peace \& Security, Vol. 19, Issue 2, pp. 103-126.

2 Гюлен, Ф. (2013), Діалог і толерантність, Український письменник, Київ, 416 с. 
із Богом треба бути собою, тобто смиренно відмовитись від усіх «надбудов», хибних уявлень про себе і максимально тверезо оцінити вихідну позицію. Духовна самоомана, на думку публіциста, блокує всі шляхи, якими християнин може прийти до справжнього спілкування з Богом. «Є лише одне місце, де зустріч із Богом, вочевидь, неможлива за визначенням: це місце уявлене», - підсумовує С. Аверинцев ${ }^{3}$. Небезпека хибних уявлень полягає у тому, що вони видають ерзац за реальність. Таким чином, самоусвідомлення перетворюється на егоїзм та егоцентризм, який, за словами С. Аверинцева, «переорієнтовуючи на ілюзію весь внутрішній склад людини, здатен звернути на неправду й те, що є піднесеним у ньому» ${ }^{4}$, діалог із Богом - на ідолопоклонство, вікно, «крізь яке можна бачити суще - те, що реальне, бо не підвладне нашому свавіллю» ${ }^{5}-$ на дзеркало.

У спілкуванні із Богом нелегко прийняти той факт, що Його воля не залежить від наших бажань і примх. С. Аверинцев ілюструє цю тезу новозавітною притчею про блудного сина, у якій батько влаштовує пишний бенкет на честь безпутного сина, який розкаюється. Натомість старший брат, який завжди був поруч із батьком, ніколи не удостоювався такого святочного ставлення. Милість Божу не завжди легко прийняти і зрозуміти, але це одна із умов справжньої віри. Публіцист нагадує, що біля витоків біблійної традиції стоїть заборона - не сотвори собі кумира. А кумир, за словами С. Аверинцева, «це матеріалізація зловісної ідеї про божество, яким можна маніпулювати. (...) Кумир - так би мовити, потрібна річ. Вибір між ним і Богом Живим Біблії - це вибір між маніпуляцією та спілкуванням» ${ }^{6}$.

Думки С. Аверинцева про високий статус спілкування співзвучні із міркуваннями Йоана Зізіуласа, на думку якого «без поняття спілкування неможливо вести мову про буття Боже»7. Зважаючи на це, спілкування набуває онтологічного значення. Однак не варто забувати, нагадує С. Аверинцев, що «основа спілкування - повага до свободи особистого буття того, 3 ким ми спілкуємось» ${ }^{8}$. Йдеться не лише про спілкування з Богом, але й про діалог із ближнім.

Підміна реальних співрозмовників власними уявленнями про них не просто загрожує успішному діалогові, але й може призводити до вибухів нетерпимості, яких зазнало минуле сторіччя. В есеї «Коли рука не стиснеться в кулак», опублікованому вперше 1990 року, саме тоді, коли С. Аверинцев почав активно виступати як публіцист, йдеться про наслідки такої підміни та про причини спалахів ворожнечі. Уява, яка нібито має допомагати нам пізнавати й описувати довколишній світ, може інколи породжувати фантоми, які уможливлюють його руйнацію. Проявів ксенофобії і нетолерантності у ХХ сторіччі цей умовивід стосується безпосередньо. «Коли німці перестали достатньою мірою природно почувати себе німцями, то вирішили, що вони раса» ${ }^{9}$. Неадекватна автохарактеристика зумовлює хибне сприйняття Іншого. Його можна вигадати, створити, а не прийняти таким, яким він є. Радянський і на-

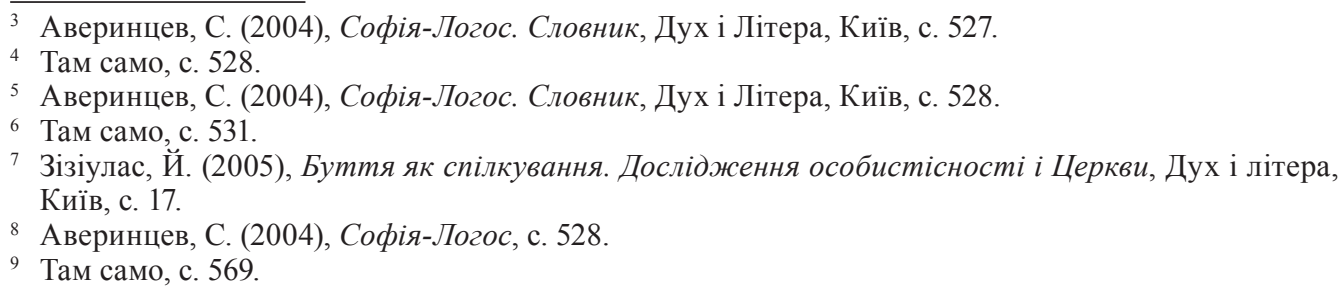


цистський тоталітарні режими пішли саме цим шляхом, борючись із «куркульством як класом» i «фашизмом» чи «міжнародним єврейством». С. Аверинцев, посилаючись на думку Карла Кереньї щодо ролі абстракцій у практиці масових убивств, зауважує, що «одна річ сказати: вбити кожного єврея, інша річ - ліквідувати єврейство. Єврейство - це абстрактна категорія, вона - ліквідується. Одна річ сказати: убити всіх людей у місті - дорослих, дітей, чоловіків, жінок, старих, навіть домашніх тварин, що перебувають у місті. (...) Інша річ сказати: стерти місто з лиця землі. Ви берете лезо і зішкрібаєте кружок на карті. Ви ліквідуєте певну абстракцію. Із абстракціями чинити розправу простіше» ${ }^{10}$. Розправі із абстракціями протистоїть постріл в конкретну людину. Публіцист наводить відомий епізод із есею Джорджа Орвелла «Згадуючи війну в Іспанії», у якому той описує, як не зміг натиснути на гачок, бо перед ним опинився не зловісний ворог, а нікчемний солдат, який біг уздовж окопу зі спущеними штанами. Англійський письменник пояснює: «Я ж їхав сюди вбивати «фашистів», а цей, який підтягував штани, - який він «фашист», просто хлопець, схожий на мене, і як в нього вистрелити?!» ${ }^{11}$ Конкретність кожної людини повертає нас від фантомів до реальності. Один із класиків філософії діалогу, Емануель Левінас, проголошував, що обличчя Іншого каже мені «Не вбивай!» ${ }^{12}$

Діалогічний етос - це справжній виклик для тоталітаризму, позаяк останній свідомо поглиблює і радикалізує відмінності між людьми. Як правило, така тактика тоталітаризму також працює з людською уявою. Прийняття діалогу як етичного орієнтиру не передбачає скасування усіх відмінностей. Навпаки, тотальна уніфікація робить діалог неможливим. С. Аверинцев наголошує, що йдеться не про припинення конфліктів між різноманітними розходженнями, а про зміну стилю конфліктів. Руйнування, наприклад, релігійних відмінностей, важливих для конфесійної самоідентифікації, для російського публіциста абсолютно неприйнятне. Усвідомлення існування чітких відмінностей між етносами чи релігіями підсилює значущість вибору. На думку С. Аверинцева, у сучасних умовах християнське віросповідання усе рідше передається у спадок і все частіше стає предметом вибору. Ситуація доленосного вибору трагічна за своїм характером, але саме «трагізм вибору робить людське духовне життя, людський вибір серйозним» ${ }^{13}$. Світ без відмінностей змальовано у знаменитій пісні Джона Леннона «Imagine», яку часто сприймають не лише як музичний твір, але й своєрідний культурний маніфест. За словами польської публіцистки Агнєшки Колаковської, образ світу без країн, без релігії, без цінностей, за які варто вбивати чи вмирати, без небес і пекла, без власності - це образ, «від якого віє моторошною порожнечею, і не тільки тому, що дрож проймає від думки про те, як - за допомогою яких репресій - можна було б (гіпотетично) досягнути такої утопії, яка суперечить людській природі, і хто б їі підтримував. Але ще й тому, що саме така у загальних рисах утопія, схоже, широко входить у сподівання ХХІ сторіччя, особливо у новій Європі» ${ }^{14}$. Відтак, думка С. Аверинцева протистоїть будь-яким спробам - чи то ліберальним, чи то тоталітарним - скасувати чи применшити різність між людьми:

${ }_{10}$ Аверинцев, С. (2004), Софія-Логос, с. 570.

${ }^{11}$ Оруэлл, Д. (2003), Памяти Каталонии. Эссе, Издательство АСТ, Москва, с. 84.

${ }_{12}$ Цит. за: Клочовський, Я. (2013), Філософія діалогу, Дух і літера, Київ, с. 12.

${ }_{13}$ Аверинцев, С. (2004), Софія-Логос, с. 572.

${ }^{14}$ Колаковская, А. (2004), «IMAGINE... Интеллектуальные истоки политкорректности», Новая Польша, № 3. URL: http://www.novpol.ru/index.php?id=200 
«Незгода людей - це дуже серйозна річ, але незгода і ворожість вельми різні поняття. Трагізм повинен бути трагізмом любові. Толерантність індиферентна і толерантність віри - настільки несхожі на світі речі. Де індиферентизм, там згасає трагедія, вогонь, що робить людину людиною. Але там, де ненависть, трагедія теж припиняється, перетворюючись на жорстоку мелодраму. Там теж все просто. Люди вибирають ненависть не в останню чергу тому, що вона рятує від трагедії» ${ }^{15}$. У цьому уривку можна знайти роз'яснення одного з ключових сучасних понять, яке однаково цікавило i С. Аверинцева, і С. Кримського - «толерантність». Толерантність цілком сумісна із твердим дотриманням власних переконань. Л. Колаковський в одному із своїх есеїв назвав «індиферентну толерантність», байдужість, «частиною нашої гедоністичної культури, в якій справді все втрачає для нас своє значення» і «філософією життя без почуття відповідальності і без жодних переконань» ${ }^{16}$. Небезпеки байдужості не варто недооцінювати, адже «зневага до правди нищить нашу цивілізацію не менше, аніж фанатизм правди. Збайдужіла більшість розчищає поле для фанатиків, які завжди знайдуться в достатній кількості» ${ }^{17}$.

С. Аверинцев наводить епізод із життя Мартіна Бубера, переконаного іудаїста, який не раз гостро сперечався із християнами. Один із його відвідувачів, теж єврей, якось завітав до робочого кабінету свого вчителя і побачив там хрест, що викликало у нього неабиякий подив. На стіні кабінету М. Бубера висіла гравюра, на якій було зображене римське гетто, а поруч із ним височів християнський храм. Публіцист цитує слова відповіді М. Бубера своєму здивованому відвідувачеві: «Так, я повісив на стіні цю гравюру, тому що в конкретній реальності історії і гетто, і церква були поруч, і гравюра нагадує про те, як насправді влаштував Бог. Можна вигадувати яку завгодно історію, але справжня одна, і в ній усі разом, поруч один біля одного» ${ }^{18}$. М. Бубер був не лише першорядним теоретиком діалогу. Він також намагався втілювати своє вчення у життя, наприклад, пропонуючи створення спільної для арабів та євреїв держави або налагоджуючи контакти з Німеччиною одразу після Другої світової війни, за що його неодноразово критикували непримиренно налаштовані ізраїльські діячі ${ }^{19}$. Зрештою, сам С. Аверинцев зауважує, що, якби у нього не було друзів серед представників інших націй - євреїв, латишів, грузинів, німців, англійців та інших - його самоусвідомлення як росіянина не було б настільки повним.

Есей «Коли рука не стиснеться в кулак», написаний напередодні розпаду Радянського Союзу, завершується попередженням, хоча автор вважає його «банальним трюїзмом»: «Будь-яка людина, що в дусі своєму вбиває іншу людину, вбиває себе. Їй дана влада, власне, над собою. I національний екстреміст має владу заподіяти справжнє лихо тільки своєму народу» ${ }^{20}$. Саме тому С. Аверинцеву як росіянинові страшно насамперед за Росію, тоді як щодо інших націй він відчуває провину, сором і співчуття. Вихідну точку для діалогу важко уявити іншою: єдиний, на кого я можу вплинути і відтак змінити - це я сам. Натомість страх С. Аверинцева зумовлений

\footnotetext{
${ }_{15}$ Аверинцев, С. (2004), Софія-Логос, с. 572.

${ }^{16}$ Колаковський, Л. (1999), Про толерантність, Міні-лекиії на максі-теми, Основи, Київ, с. 44.

${ }^{17}$ Там само, с. 45.

${ }^{18}$ Цит. за: Аверинцев, С. (2004), Софія-Логос, с. 573.

19 Див.: Кельнер, М. (2000), «Жизнь и творчество Мартина Бубера», Лехаим, №6 (98). URL: http:// www.lechaim.ru/ARHIV/98/kelner.htm

20 Аверинцев, С. (2004), Софія-Логос, с. 574.
} 
тим, що енергія злоби, вироблена у надрах Росії, виллється на інших, але вона може знищити і саму Росію. Через майже тридцять років після оприлюднення ці слова, сформульовані не як політичний лозунг, а як вдумлива і вкрай особиста пересторога, звучать, як ніколи, актуально. Однак, якщо у 1990-х роках ім'я С. Аверинцева було ледве не культовим і до його думок прислухались, то з початку 2000-х, за спостереженням Гасана Гусейнова, його читають вже набагато менше ${ }^{21}$. Політична, суспільна й інтелектуальна атмосфера у Росії з початку 2000-х років свідчить про те, що застережень С. Аверинцева не почули. Представник російської інтелігенції, історик Андрій Зубов у 2014 році порівнював дії Росії із нацистською Німеччиною22. У 1993-1994 роках С. Аверинцев полемізував із ним щодо питання християнського осмислення російської історії, яке вчений виклав у своїй статті «Шляхи Росії», опублікованій у журналі «Континент» ${ }^{23}$. С. Аверинцев не погодився із деякими тезами А. Зубова, а також із досить категоричним і різким тоном, яким вони були висловлені, однак висловив підтримку тому, що автор віддав перевагу страху Божому перед національним «тріумфалізмом» ${ }^{24}$. Можливо, саме неприйняття національного «тріумфалізму» й зверхності - риса, яка об'єднала обох публіцистів, незважаючи на доволі значні розходження в оцінках, - дала змогу А. Зубову в березні 2014 року, коли Росія анексувала український Крим, виступити із різкою критикою своєї країни.

Страх С. Аверинцева за майбутнє своєї країни базується на проблемі недостатнього осмислення й подолання тоталітарного минулого. Публіцист присвячує цій темі кілька своїх виступів. Небезпека тоталітаризму полягає у тому, що його дія не обмежується хронологічними рамками існування держав, відповідальних за його впровадження. Наприклад, у сучасному мегаполісі, де кожна людина - сама у натовпі, де ближнього оголошено неіснуючим, можна розгледіти риси тієї атомізації, яка уможливлювала у 30-ті роки минулого сторіччя функціонування сталінського терору. Автор цитує в цьому контексті слова свого грузинського приятеля: «Чому мені в Москві буває тяжко? Що, ти гадаєш, через брутальність? Ні. Брутальності в нас теж вистачає. У моєму Тбілісі мене можуть побити; але той, хто б'є, буде уявляти, що в нього є підстави мене ненавидіти. А тут у мене таке почуття, що мене можуть навіть і вбити, так і не помітивши, що це я» ${ }^{25}$. Або, спостерігаючи у Відні демонстрацію, присвячену арабо-ізраїльському протистоянню, на якій молоді люди, крокуючи в такт, вигукували гасло «Eins, zwei, drei - Palästina frei», публіцист дивується, чому сучасна молодь, яка не зазнала прямого згубного впливу тоталітарних практик, демонструє «ту саму готовність надто довірливо, без найменшого відчуття особистої відповідальності, підхоплювати і хором вигукувати підказані медіальним механізмом істини, якою свого часу так широко користувалися тоталітарні системи, створюючи i Hitlerjugend, i комсомол» ${ }^{26}$. Це гасло також демонструє спрощену картину

${ }^{21}$ Гусейнов, Г. (2014), «Интеллигент или поэт, гуманитарий или проповедник? С.С.Аверинцев в своем времени», Гефтер. URL: http://gefter.ru/archive/15000

22 Зубов, А. (2014), «Это уже было», Ведомости, 1 мар. URL: http://www.vedomosti.ru/opinion/ articles/2014/03/01/andrej-zubov-eto-uzhe-bylo

23 Див.: Зубов, А. (1993), «Пути России», Континент, № 1 (75), Зубов, А. (1994), «Опыт метанойи», Континент, № 3 (81).

${ }^{24}$ Аверинцев, С. (1994), «По поводу статьи А. Зубова «Пути России», Континент, № 81, с. 174-178.

25 Аверинцев, С. (2004), Софія-Логос, с. 570.

26 Там само, с. 564. 
світу, у якій комплексні проблеми зводяться до примітивних поділів на «добрих» і «поганих» або підміняються політкоректними евфемізмами. С. Аверинцев наводить промовистий факт, що у пізньосталінський період логіку, якою тепер послуговується політична коректність, використовували для маскування репресій проти єврейської інтелігенції, хоча офіційна преса кваліфікувала її як боротьбу з «мерзенними космополітами».

Складність подолання тоталітаризму полягає насамперед у тому, що він, на відміну від архаїчних деспотій чи авторитаризму, вражав не лише верхівку суспільства, але й пронизував усі верстви, роблячи усіх мимовільними співучасниками злочинів. Саме тому подолання спадщини тоталітаризму - це проблема не тільки юридична, але й моральна. Послуговуючись згаданою вище класифікацією американського антрополога Рут Бенедикт, публіцист говорить про протистояння культури совісті культурі сорому. Якщо остання передбачає «збереження обличчя» і приховування незручних сторінок біографії і притаманна культурам Сходу, то перша базується на відчутті особистої відповідальності за скоєне і сказане, i, на переконання С. Аверинцева, саме з нею пов'язане майбутнє європейської традиції свободи. Посилаючись на приклад О. Солженіцина, публіцист висловлює сподівання, що базована на християнській спадщині культура сумління об'єднує росіян із Заходом. Якщо це сподівання підтверджується у випадку самого С. Аверинцева, то не варто забувати, що викриття, які зробив Солженіцин у радянські часи, не вберегли його від шовіністичних випадів після розпаду СРСР.

Подолання тоталітаризму спрямоване на відновлення справжніх людських взаємовідносин. Відчуття особистої відповідальності, спротив «хоровому співу» й атомізації - це шляхи, які ведуть до відновлення діалогічного етосу у статусі етичної настанови. Для С. Аверинцева моделлю таких взаємовідносин є сім'я, яка дарує нам перший досвід зустрічі з Іншим. Розглядаючи сім'ю крізь призму християнської духовності, публіцист протистоїть тим поглядам, які відводять їй роль мало не основної цеглини у фундаменті тоталітаризму. Сім'я - це середовище діалогу, зокрема й діалогу між поколіннями. Для С. Аверинцева, як філолога й історика культури, тема міжгенераційного спілкування була надзвичайно близькою. Це виявляється не лише у тематиці його публікацій, але й навіть у композиції деяких його книжок. До прикладу, остання збірка статей, яку уклав С. Аверинцев, має промовисту назву «Зв’язок часів» ${ }^{27}$. Досвід минулих століть і культурна пам'ять, яка починається із спілкування із старшими членами родини, - це ще один спосіб боротьби із рецидивами тоталітаризму.

Заперечуючи тим, хто вважає «міцну сім’ю» основою тоталітарних режимів, С. Аверинцев нагадує, що останні, навпаки, намагалися їі зруйнувати, відтворивши і1і згодом за власними канонами. Тоталітаризм тим і небезпечний, що спочатку скасовує усі табу, а потім їх різко посилює. Публіцист акцентує на тому, що ранній нацизм і комунізм мали яскраво виражені риси молодіжної субкультури (гасло «Комунізм - це молодість світу»), організовуючи власні молодіжні організації і борючись iз міщанськими пережитками, наприклад, встановленням різдвяної ялинки. Згодом, коли вони, експлуатуючи риторику оновлення й антипуританства (наприклад, комуністичні акції «Геть сором!»), приходили до влади, то не гребували впровадженням

${ }^{27}$ Аверинцев, С. (2005), Связь времен, Дух і Літера, Київ, 448 с. 
звичаїв, з якими допіру боролись. І справді, «сім’я, членам якої «дозволено» скаржитися одне на одного в партком, - уже не зовсім сім'я, це щось інше» ${ }^{28}$.

Саме руйнуванням сімейних пут С. Аверинцев пояснює різноманітні суспільні аберації. Не дарма один із його останніх публічних виступів має назву «Солідарність поколінь як фактор громадянської свободи» ${ }^{29}$. У ньому він наводить спогад, який ілюструє передумови становлення тоталітаризму красномовніше, аніж будьякі історичні узагальнення: «Я чув у дитячі роки від старої жінки сільського походження розповідь про те, як у їхньому селі ще перед тим, як їхню церкву зламали, місцеві комсомольці у престольне свято залізли на дзвіницю і поливали своєю сечею хресний хід, тобто своїх батьків, бабусь і дідусів... Ще раз - це були місцеві парубки, не якісь посланці з міста, тим більше не інородці. Такий епізод змушує серйозно замислитися над тоталітарною експлуатацією генераційних суперечностей» ${ }^{30}$. Але й сучасність, якій С. Аверинцев в одному із інтерв’ю радить не підтакувати, «перш за все хоча б тому, що це негарно» ${ }^{31}$, зацікавлена в абсолютизації генераційного розриву: індустрія реклами і споживацтва, з одного боку, і сучасний лібералізм з його амбіцією загального перевиховання людства - 3 іншого, продовжують становити серйозну загрозу солідарності поколінь, а відтак і демократії.

Посилаючись на власний сімейний досвід, згадуючи свого батька, який народився 1875 року, «в один рік зі Швейцером і Томасом Манном», і матір, яка «встигла мигцем побачити Льва Толстого», С. Аверинцев розповідає, що саме досвід солідарності із атмосферою родинного кола давав змогу протистояти зовсім іншій атмосфері навколишнього суспільства, у якому традиційна сім'я перетворилась на знаряддя поширення тоталітарних практик. Для С. Аверинцева власне сімейне коло стало своєрідною фортецею духовності та діалогу. Саме тому публіцист схильний розглядати традиційний конфлікт «батьків і дітей» у діалогічній перспективі: «Так, ми бачимо щось, чого не бачать старші, але якщо вони бачили те, чого справді не бачили ми, наше різнодумство з ними примушує замислитись, дає поштовх думці - за умов, що ми сприймаємо їхній досвід серйозно нарівні із власним» ${ }^{32}$.

\section{4. Висновки}

С. Аверинцева цікавив насамперед етичний вимір діалогу ${ }^{33}$. Автор бачив у ньому не тільки метод подолання тоталітарного минулого, але й моральний орієнтир для сучасності і майбутнього. Увага публіциста до діалогу свідчить не стільки про те, що призабуті свої й актуалізовані закордонні ідеї гуманітаристики стали набутком публічних дискусій, скільки про реальну суспільну атмосферу і про дефіцит справжнього діалогу між людьми. Тому його роздуми мають не лише теоретичну вартість. Пишучи про діалог як ціннісний орієнтир на основі власного досвіду й спостережень, він надає абстрактному поняттю особистісного виміру.

${ }_{28}$ Аверинцев, С. (2004), Софія-Логос, с. 597.

${ }^{29}$ Аверинцев, С. (2005), Связь времен, с. 419-427.

${ }^{30}$ Аверинцев, С. (2004), Софія-Логос, с. 597.

${ }_{31}$ Аверинцев, С. (2004), Софія-Логос, с. 585.

32 Там само, с. 599.

${ }^{33}$ Малахов, В., Даренський В. (2011), Діалог sub specie ethicae, Парапан, Київ, 280 с. 


\section{СПИСОК ЛІТЕРАТУРИ}

1. Аверинцев, С. (1994), «По поводу статьи А. Зубова «Пути России», Континент, № 81, с. 174-178.

2. Аверинцев, С. (2005), Связь времен, Дух і Літера, Київ, 448 с.

3. Аверинцев, С. (2004), Софія-Логос. Словник, Дух і Літера, Київ, 656 с.

4. Гусейнов, Г. (2014), «Интеллигент или поэт, гуманитарий или проповедник? С.С.Аверинцев в своем времени», Гефтер. URL: http://gefter.ru/archive/15000 (ocтанній перегляд 28 червня 2019)

5. Гюлен, Ф. (2013), Діалог і толерантність, Український письменник, Київ, 416 с.

6. Зізіулас, Й. (2005), Буття як спілкування. Дослідження особистісності і Церкви, Дух і літера, Київ, 276 с.

7. Зубов, А. (1994), «Опыт метанойи», Континент, № 3 (81).

8. Зубов, А. (1993), «Пути России», Континент, № 1 (75).

9. Зубов, А. (2014), «Это уже было», Ведомости, 1 мар. URL: http://www.vedomosti.ru/ opinion/articles/2014/03/01/andrej-zubov-eto-uzhe-bylo (останній перегляд 20 червня 2019)

10. Кельнер, М. (2000), «Жизнь и творчество Мартина Бубера», Лехаим, №6 (98). URL: http://www.lechaim.ru/ARHIV/98/kelner.htm (останній перегляд 20 вересня 2019)

11. Клочовський, Я. А. (2013), Філософія діалогу, Дух і літера, Київ, 224 с.

12. Колаковская, А. (2004), «IMAGINE... Интеллектуальные истоки политкорректности», Новая Польша, № 3. URL: http://www.novpol.ru/index.php?id=200 (останній перегляд 02 вересня 2019)

13. Колаковський, Л. (1999), Про толерантність, Міні-лекції на максі-теми, Основи, Київ, с. 41-49.

14. Малахов, В., Даренський В. (2011), Діалог sub specie ethicae, Парапан, Київ, 280 с.

15. Оруэлл, Д. (2003), Памяти Каталонии. Эссе, Издательство АСТ, Москва, 321 с.

16. Petito, F. (2007), "The Global Political Discourse of Dialogue among Civilizations: Mohammad Khatami and Václav Havel", Global Change, Peace \& Security, Vol. 19, Issue 2, pp. 103-126.

\section{REFERENCES}

1. Averintsev, S. (1994), "Regarding A. Zubov’s article "Ways of Russia”, Continent, № 81, pp. 174-178.

2. Averintsev, S. (2005), Connection of Times, Duh i litera, Kyiv, 448 p.

3. Averintsev, S. (2004), Sophia-Logos. A Vocabulary, Duh i litera, Kyiv, 656 p.

4. Huseinov, H. (2014), "Intelligent or Poet, Humanitarian or Preacher? S. S. Averintsev in his Time", Gefter, available at: http://gefter.ru/archive/15000 (accessed 28 June 2019)

5. Gulen, F. (2013), Dialogue and Tolerance, Ukrainskiy Pysmennyk, Kyiv, 416 p.

6. Zizioulas, J. (2005), Being as Communion, Duh i litera, Kyiv, 276 p.

7. Zubov, A. (1994), “The Metanoia Experience”, Continent, № 3 (81).

8. Zubov, A. (1993), "Ways of Russia", Continent, № 1 (75).

9. Zubov, A. (2014), "It Happened Before", Vedomosti, 1 March, available at: http:// www.vedomosti.ru/opinion/articles/2014/03/01/andrej-zubov-eto-uzhe-bylo (accessed 20 June 2019). 
10. Kelner, M. (2000), “The Life and Work of Martin Buber”, Lechaim, №6 (98), available at: http://www.lechaim.ru/ARHIV/98/kelner.htm (accessed 20 September 2019).

11. Klochovskiy, J. A. (2013), Philosophy of Dialogue, Duh i litera, Kyiv, 224 p.

12. Kolakovskaya, A. (2004), "IMAGINE ... The Intellectual Origins of Political Correctness", Novaya Polsha, №3, available at: http://www.novpol.ru/index.php?id=200 (accessed 02 September 2019).

13. Kolakovskiy, L. (1999), On Tolerance, Mini-lectures on Maxi-topics, Osnovy, Kyiv, pp. 41-49.

14. Malakhov, V. \& Darenskiy, V. (2011), Dialogue sub specie ethicae, Parapan, Kyiv, 280 p. 15. Orwell, G. (2003), Homage to Catalonia, AST, Moscow, 321 p.

16. Petito, F. (2007), "The Global Political Discourse of Dialogue among Civilizations: Mohammad Khatami and Václav Havel", Global Change, Peace \& Security, Vol. 19, Issue 2, pp. 103-126.

\title{
THE CONCEPT OF DIALOGUE IN SERGEY AVERINTSEV'S PUBLICISM
}

\author{
Andrii Melnyk \\ Ivan Franko National University of Lviv, \\ Generala Chuprynky Str. 49, 79044, Lviv, Ukraine \\ e-mail: andriy.melnyk@lnu.edu.ua \\ https://orcid.org/0000-0003-1646-008X
}

The subject of the article is publicistic writings of Russian philologist, historian of culture and influential public intellectual of the 1990s - early 2000s, Sergey Averintsev, devoted to overcoming of the totalitarian heritage and, in particular, the concept of dialogue. Averitsev's reasoning about the dialogue can be reduced to the thesis that this is one of the most effective methods of overcoming manipulation during the communication. Dialogical communication involves discarding misconceptions about interlocutor and accepting his otherness. S. Averintsev stressed that this feature of dialogue is important in communication both with people and with God. According to the publicist, the dialogical ethos does not lead to the elimination of differences, but, conversely, their acceptance and deep awareness. The article also outlines S. Averintsev's views on tolerance, which, in his opinion, is opposed in one hand to indifference and fanaticism on the other. The publicist is concerned about the proliferation of "vicious energy" and "national triumphalism" in Russia in the early 1990s. In this context, his concerns were prophetic and fully fulfilled in 2014. The author emphasizes the importance of a dialogical ethos for overcoming totalitarianism that exploited intergenerational conflicts. According to S. Averintsev, dialogue between generations is a necessary condition of civil liberty. S. Averintsev's attention to the dialogue shows not so much that the forgotten and actualized foreign ideas of the humanities became the result of public discussions, but rather of the real social atmosphere and the lack of genuine dialogue between people. Writing about dialogue as a value benchmark based on one's own experience and observations, S. Averintsev gives a personal dimension to an abstract concept.

Key words: publicism; dialogue; values; Sergey Averintsev; Russia. 